problems of distinguishing between equivalent and non-equivalent protons and of synthesizing spectra for various values of hyperfine splitting constants. In some radicals, for example, triphenylmethyl, which can be used as a reference, the total of spin densities computed was greater than unity becauso densities at some carbon atoms have spin opposite to that of the unpaired electron (although the signs are not determined by the electron spin resonanco data).

On irradiation at low temperatures, solid polymers frequently yield measurable free radical concentrations which decay slowly at room temperature. Mr. M. G. Ormerod (Royal Military Collego of Science, Shrivenham) described the use of electron spin resonance as a check of purity, for detection of intermediates, and for the estimation of degree of cross. linking; future work might include the effects of water and of radiation protection additives. Measurements with drawn fibres sometimes enabled the nature of the radical(s) to be identified, but resolution was lower than with irradiated single crystals, which formed the subject of the talk by Dr. A. Horsfield (Varian A.G., Zürich). In dilute free-radical systems trapped among the host molecules of the crystal matrix, not only can the irradiation darnage, such as stripping of a hydrogen atom, be investigated, as with polymers, but also the anisotropic hyperfino splitting associated with specific chemical groups may be obtained. Among the simple negative inorganic radicals studied recently by $D$. $H$. Whiffen and collaborators, Dr. Horsfield mentioned the $\mathrm{SO}_{3}{ }^{-}$ ion obtained from salts containing the $-\mathrm{SO}_{3}{ }^{-}$ group; the single line spectrum is split into a quadruplet by the sulphur-33 nucleus $(I=3 / 2)$ in its 0.7 per cent natural abundance. In $\mathrm{CH}\left(\mathrm{SO}_{3}\right)_{2}{ }^{2-}$, hyperfine splitting due to protons on nearby $\mathrm{CH}_{2}\left(\mathrm{SO}_{3}\right)_{2}{ }^{2-}$ host ions has also boen detected in crystals of the potassium salt.

Dr. A. Carrington (University of Cambridge) turned from free radicals to the other main field of application of electron spin resonance to chemistry, transition metal ions. The effect of the exact ligand symmetry on $g$-values and the fine structure resulting from several unpaired electrons were considered for dilute crystals of complexes. Hyperfine interaction with ligand nuclei possessing magnetic moments as with the nitrogens in hamoglobin, could provide crystallographic information. Finally, Dr. Carrington pointed out that, whereas the meeting had been devoted so far to the study of ground states, electron spin resonance could provide a means of studying excited states. Recontly, Hutchison had detected resonance in the phosphorescent state obtained from ultra-violet irradiation of a dilute solid solution of naphthalene in durene.

\title{
SOUTH-EASTERN UNION OF SCIENTIFIC SOCIETIES ANNUAL CONGRESS
}

\begin{abstract}
A 'T the invitation of the Horsham Uxban District A Council and the Horsham Natural History Society, the South-Eastern Union of Scientific Societies held its sixty-seventh annual congress at Horsham during May 25-27 under the presidency of Dr. Maurice Burton. 'The headquarters of the congress was at Collyer's School, by kind permission of the headmaster.

Tho delegates were welcomed by the chairman of the Urban District Counvil, Councillor Cullen, and J. Southwood, the president of the Natural History Socioty. They emphasized the need of collecting information regarding the footpaths in and around Horsham; continual developmont had caused the loss of many paths and often there was considerable difference between the amenities of an ancient pathway and the alternative diversion.
\end{abstract}

'The young naturalists' evening consisted of a 'brains trust', questions being debated by a panel under the chairmanship of Maxwell Knight. The panel particularly stressed the desirability of biological control whero damage was caused by animals, pointing out that spraying with insecticides over long periods cannot be justified. There was an increase in the mortality-rate of birds last yoar, one causc being that insufficient notice was taken of the manufacturnrs' instructions; another was the careless throw. ing aside of used containers with contaminated watcr.

The presidential address was given by Dr. Maurice Burton, whose subject was "The Fallibility of Human Observation". Wishing to know the differenco be. tween biology and natural history, he had consulted The Oxford Dictionary, which defined natural history as "the unintelligent study of biology". Although startled at first, he had to agree that this was correct, although the choice of wording was unfortunate. Scoing is a purely physical process, to be likened to the operation in a camera, while observing is this plus other mental processes. It has often been said that it is "far more virtuous to observe than to see", but this is not always correct. Dr. Burton spoke of his experience when surprised by the appearance of a white bird in his holly tree. On using his binoculars he discovered he had been looking at the underside of the holly leaves; mombers of his family at the same time experienced the same illusion. He followed with the example of a class shown a drawing of an isosceles triangle with a rectangle attached to the centre of the base. Halves of the class wero shown the diagram independently, one having it described as a trowel, the other as a Christmas tree. Latcr, when asked to draw what they had seen, they showed all graduations from a trowel with a long handle to a Christmas treo. On another occasion he asked a friend, well informed on the subject-matter, to holp by proof reading. Tho galley and paginated proofs were passed, but, on receiving his anthor's copy, he was dismaycd to find a caption under an illustration spelt incorrectly. With tho book open at this page on his desk, he was visited by the proof roador who, glancing from a distance of $3 \mathrm{ft}$., exclaimed: "Did $\mathbf{I}$ pass that ?" His observation during proof reading made him see what he harl cxpected, not, what was.

The important thing in studying animal behaviour is to look, look and look, to allow the impression to soak in, not permitting a previous impression to be formed. Dr. Burton considered that vorbal pictures ran the risk of being wrong; drawings were better. He showed and commonted on a number of slides dealing with the 'Loch Ness monster'; his examina- 
tion had convinced him that the creature drawn and photographed was an otter; the other pictures were of a motor-boat. He concluded by saying that his analysis of this problem showed that maybe the dictionary was right and a naturalist could be an unintelligent biologist.

The presidential address to the Zoological Section was given by R. M. Long, on "Butterflies and Moths of the Horsham Area". The address was illustrated by colour slides from the president's photographs, dealing mainly with the camouflage of many of the species in the area. He spoke of the success achieved with his mercury-vapour-lamp trap: as many as a thousand specimens were taken on a good night. $\mathrm{He}$ had recorded 31 species of butterfly and 347 of moth in his garden noar the Carfax at the town centre. $\mathrm{He}$ asked that, when particular trees and hedgerows were the habitat of the rarer species, the Council for Nature and the County Naturalist Trust be notified to cnable an order to be obtained for their preservation.

The Archæological Section was addressed by the president, G. P. Burstow, on "Recent Excavations in Sussex". He spoke of the excavations with which he had been associated, especially at Monkdown Court, near Findon, where three years work had revealed 900 post holes of an iron-age village occupied between 500 and 300 в.c. There was evidence of drying racks, storage pits and a quantity of pottery with hæmatite surface. The site was later occupied by the RomanoBritish, a shrine connected with the worship of the ox had been uncovered, a possible association with a local Celtic god. Vast quantities of Roman pottery had been recovered, and many bronze objects, notably a plaque of a charging boar. Mr. Burstow described other excavations at Ranscomb Hill near Mount Caburn and Balcombe quarry. It was in middle Sussex where research work was most needed, a mistaken idea that it was unoccupied in ancient times being due to insufficient archæologists having been interested in the area.

The president of the Botanical Section, D. McClintock, chose as the title of his address "Alien Plants in South-east England". He spoke of the recent introductions and of the probable manner in which they arrived. Most were introduced by man, many from the Mediterranean area, then distributed by animals, being carried from place to place in their wool or fur. The bomb craters of the War were favourite sites, providing a large number of species. Buddleia was an outstanding example, being introduced from China as a rather rare plant in 1887; it was widely distributed in the countryside by 1926 .

Dr. R. Thurrell, as president of the Geological Section, gave an address on "Aspects of the Geology of the Horsham District". His talk was introductory to the excursion he was conducting during the congress. After mentioning that the area was now being examined in detail by the Geological Survey, he outlined the history of its investigation from early times. The Romans used Horsham Stone together with hardened clay as the foundation of the Stane Street at Slinfold. Iron was obtained from the ironstone in the Hastings Beds up to 1550; later limonite, from the base of the Wadhurst Clay and from the Weald Clay underlying the Horsham Beds, was the basis of the iron industry.

Mantell could be regarded as the pioneer of the systematic study of Wealden geology, his discovery of the remains of giant reptiles attracting interest as well as adding considerably to the knowledge of the conditions prevailing at the time of the deposition of the beds. The main uses of the Horsham Stone have been for roofing tiles, flag-stones and walls for farm buildings. Dr. Thurrell concluded by describing the method of capture of minor streams by the River Arun when, on surface examination, there would appear to be more likely directions for their flow.

Miss Joyce Pope addressed the delegates on the upbringing of young animals by human beings. Most people liked watching the development of young animals whether they be white mice or gorillas. At the onset Miss Pope said she wished to emphasize that both young birds and mammals are around alone before they had finished with parental care and it was a mistake to take them and attempt hand-rearing, for the parents were often close by and would be tending them. The exception was with those which had been abandoned or injured, often wished on you by friends. Even then the difficulty of the task should be realized and, where recovery seemed hopeless, it would be kinder to dispatch them painlessly. Voles were very good pets and when they were in the suckling stage she had found it better to feed with a small paint brush rather than with a fountain pen filler. Friendship with a hand-reared animal was apt to end with the animal 'becoming itself', becoming nervous and bad tempered, so one had to prepare it to fend for itself before liberating it in its native habitat. Miss Pope then showed the film "Elsa, the Lioness" to illustrate some of the points of her address.

Weather conditions, although troublesome, permitted the full excursion programme to be carried out. The botanists were conducted by 0 . Buckle on the chalk downs surrounding Chanctonbury Ring, the zoologists visited the secluded parts of St. Leonards Forest, under R. M. Long's guidance, to study the effects of reafforestation on wild life and to examine the working of the charcoal industry. The geological party, numbering seventy, visited the more important outcrops and exposures of the Wealden Series in the Horsham district under the direction of Dr. R. Thurrell.

The excellent arrangements for the congress were undertaken by the Horsham Natural History Society, for whom Mrs. R. Hurst acted as honorary secretary. F. J. EPPS

\section{TARONG PYGMIES IN NORTH BURMA}

$\mathrm{D}^{\mathrm{c}}$ URING March-April 1962 a team from the Burma Medical Research Society carried out an expedition to the Arumdum area $\left(97^{\circ} 40^{\prime}-97^{\circ} 45^{\prime} \mathrm{E}\right.$., $28^{\circ} 5^{\prime}-28^{\circ} 10^{\prime}$ N.) in the Adung Long Valley in the northernmost part of Burma. The primary object of the expedition was to study the recently discovered Tarongs - a pygmy tribe living in that area.
The team was led by Prof. M. Mya-Tu of the Department of Physiology, University of Rangoon, other members being Dr. Ko Ko, Dr. Aung Than Batu and Dr. Kywe Thein of the Directorate of Health, Burma, and Dr. C. J. R. Francis and U Than Tun Aung Hlaing of Prof. Mya-Tu's Department. 